\title{
Assessment of the GHG Reduction Potential from Energy Crops Using a Combined LCA and Biogeochemical Process Models: A Review
}

\author{
Dong Jiang, ${ }^{1}$ Mengmeng Hao, ${ }^{1,2}$ Jingying Fu, ${ }^{1,2}$ Qiao Wang, \\ Yaohuan Huang, ${ }^{1}$ and Xinyu Fu ${ }^{1,2}$ \\ ${ }^{1}$ Institute of Geographical Sciences and Natural Resources Research, Chinese Academy of Sciences, 11A Datun Road, \\ Chaoyang District, Beijing 100101, China \\ ${ }^{2}$ University of Chinese Academy of Sciences, Beijing 100049, China \\ ${ }^{3}$ Satellite Environmental Application Center, Ministry of Environmental Protection, Beijing 100094, China
}

Correspondence should be addressed to Jingying Fu; fujy@lreis.ac.cn

Received 17 April 2014; Accepted 26 May 2014; Published 17 June 2014

Academic Editor: Yang-Chun Yong

Copyright (c) 2014 Dong Jiang et al. This is an open access article distributed under the Creative Commons Attribution License, which permits unrestricted use, distribution, and reproduction in any medium, provided the original work is properly cited.

\begin{abstract}
The main purpose for developing biofuel is to reduce GHG (greenhouse gas) emissions, but the comprehensive environmental impact of such fuels is not clear. Life cycle analysis (LCA), as a complete comprehensive analysis method, has been widely used in bioenergy assessment studies. Great efforts have been directed toward establishing an efficient method for comprehensively estimating the greenhouse gas (GHG) emission reduction potential from the large-scale cultivation of energy plants by combining LCA with ecosystem/biogeochemical process models. LCA presents a general framework for evaluating the energy consumption and GHG emission from energy crop planting, yield acquisition, production, product use, and postprocessing. Meanwhile, ecosystem/biogeochemical process models are adopted to simulate the fluxes and storage of energy, water, carbon, and nitrogen in the soil-plant (energy crops) soil continuum. Although clear progress has been made in recent years, some problems still exist in current studies and should be addressed. This paper reviews the state-of-the-art method for estimating GHG emission reduction through developing energy crops and introduces in detail a new approach for assessing GHG emission reduction by combining LCA with biogeochemical process models. The main achievements of this study along with the problems in current studies are described and discussed.
\end{abstract}

\section{Introduction}

The increasing consumption of fossil fuel and current ecological environmental problems are global challenges. Plantbased bioenergy liquid fuel (including biofuel ethanol and biodiesel) is an effective way to relieve the energy crisis and also protect the environment due to its advantages of cleanness, safety, and reproducibility $[1,2]$. After nearly 10 years, the worldwide production of liquid fuel is developing very rapidly, increasing from 0.96 billion in 2001 to 21.4 billion in 2011. The European Union, the USA, and Brazil are the main forces in the development of the biomass energy industry [3]. Although the development of the global biofuel industry has shown a great trend driven by the energy requirement and related policies, there are still many challenges in largescale production. The main raw material of liquid biofuel production is currently cultivated crops. Soybean and corn are widely used in the USA and rapeseed and soybean are used in the European Union for biodiesel development. In Brazil, sugarcane is used for ethanol development [4]. Relatively accurate conclusions regarding productivity and environmental benefits may be drawn based on years of cultivated experience. The production of bioethanol and biodiesel by different energy plants and process techniques can reduce greenhouse gas (GHG) emissions by $12-125 \%$ compared with traditional fossil fuels [5-7]. Adler et al. used the DAYCENT biogeochemistry model to assess the soil GHG fluxes and biomass yields for corn, soybean, alfalfa, 
hybrid poplar, reed canarygrass, and switchgrass as bioenergy crops in Pennsylvania, USA. The results showed that all cropping systems considered provided net GHG sinks. The net GHG emissions of switchgrass, reed canarygrass, cornsoybean rotation, corn-soybean-alfalfa rotation, and hybrid poplar were reduced by $-114 \%,-84 \%,-38 \%,-41 \%$, and $-117 \%$, respectively [6]. Large-scale production of biodiesel in the UK was found to save $26 \%$ of GWP [8]. However, Jatropha and other noncrop energy plants have not been used long enough to generate sufficient data. The key problem of noncrop energy plants scale development is how to scientifically estimate the potential of GHG emission reduction [9]. If this problem can be solved, the development of biological liquid fuels can be more accurately evaluated and more reasonably planned.

The main purpose for the development of biological liquid fuel is to reduce GHG emissions, but great uncertainty remains regarding its comprehensive environmental impact. Some researchers believe that the patterns of land use change will affect the GHG emissions. These researchers believe that biological liquid fuel development would have a negative impact on the environment if the GHG emissions caused by the land use pattern changes were under consideration $[10$, 11]. However, according to the latest survey of the American Department of Energy, certain assumptions in the studies above have obvious problems. They assumed that 30 billion gallons of ethanol would be produced from corn annually until 2015, but only 1.5 billion gallons were planned to be produced according to the Energy Independence and Security Act [12]. They also assumed that massive deforestation would occur during the development of biomass energy, but most of the forests were excluded in the planning. Therefore, the assumption of a large amount of cultivated land being occupied is not correct because the biomass energy is developed based on the sparse forest land, sparse shrub land, sparse grassland, shoal/bottomland, and bare land rather than the cultivated land [13].

Regarding the net energy balance problems during production, ethanol from corn yields $25 \%$ more energy than the energy invested in its production, whereas biodiesel from soybeans yields 93\% more [5]. Switchgrass produces $540 \%$ more bioethanol than nonrenewable energy consumed [12], which shows a great advantage of the second generation of biological liquid fuel. Some controversy also exists as to whether the development of bioliquid fuel will reduce GHG emissions. Some studies have indicated that GHG emissions can be reduced by $12-125 \%$ with bioliquid fuel production compared to traditional fossil fuels [12]. Bioethanol production from corn can reduce GHG emissions by $13 \%$. The second generation biofuel can reduce more GHG emissions along with the development of process techniques [14]. Bioethanol production from switchgrass instead of fossil fuels can reduce GHG emissions by 94\% [15]. Sasaki et al. [16] developed biomass change and harvest models to estimate the woody biomass availability in forests under the current management regime. The total annual production of woody biomass is 563.4 million tons (11.3 EJ) over the same period between 1990 and 2020. The total energy consumption in Southeast Asia was estimated at 6.4 EJ in 1990 and 15.7 EJ in 2006, increasing approximately by $9.0 \% \mathrm{yr}^{-1}$. Energy from wood fuels in Southeast Asia (excluding Singapore and Brunei) was estimated at 2.4 EJ in 1993 or approximately $33.1 \%$ of the total energy consumption in that year. Energy from wood fuels in this region increased by approximately $2.5 \% \mathrm{yr}^{-1}$ on average between 1992 and 1995 [17, 18]. Therefore, without effective policies to reduce deforestation and forest degradation, an energy shortage is likely to occur in Southeast Asia. The carbon emission reductions associated with using woody biomass instead of fossil fuels to generate energy are estimated at $281.7 \mathrm{TgC} \mathrm{yr}^{-1}$ for replacing coal, 225.3 ${\mathrm{TgC} \mathrm{yr}^{-1}}^{-1}$ for replacing petroleum products, and 169.0 $\mathrm{TgC}_{\mathrm{yr}}{ }^{-1}$ for replacing natural gas throughout the modeling period using carbon coefficients of $25 \mathrm{kgC} \mathrm{G}^{-1}$ for coal, $20 \mathrm{kgC} \mathrm{GJ}^{-1}$ for petroleum products, and $15 \mathrm{kgC} \mathrm{GJ} \mathrm{GJ}^{-1}$ for natural gas [16].

Some controversy remains about the effects of biological liquid fuel development on the economy, society, and environment. Therefore, many countries have begun to reevaluate their future biofuel development strategies, exploring strategies that have smaller negative effects on the economy, society, and environment. For example, the European Union decided to postpone the implementation of their goal of replacing $10 \%$ of their transportation energy with biological liquid fuel by 2020, and the United States government claimed to assess and monitor the sustainability of biological liquid fuel development [19]. China's biofuel industry is also witnessing rapid development. However, the development of the biodiesel industry is still faced with many uncertainties, among which the accurate estimation of the potentiality of raw material supply, net energy production, and GHG emission reduction is the most crucial issue.

The main objectives of this study are the following: (1) to review the state-of-the-art method for assessing the GHG emission reduction by developing energy crops and (2) to introduce a new approach for assessing the GHG emission reduction by combining life cycle analysis (LCA) with biogeochemical process models. This paper focuses on estimating the GHG reduction of noncrop energy plants, especially in the stages of growing, managing, and harvesting. In addition, the GHG caused by direct land-use changes were considered, while the GHG caused by indirect land-use change were beyond the scope of this paper.

\section{Life Cycle Analysis}

To become a substitute for fossil fuels, bioliquid fuel should be able to provide net energy, bring environmental and economic benefits, and not reduce the food supply during mass production [6]. LCA is used to evaluate the energy consumption of a product or system throughout its life cycle, including raw material acquisition, production, product use, and postprocessing [3]. In recent years, LCA has been widely used as a complete comprehensive analysis method in bioenergy assessment studies. By comparison with fossil fuels, the consumption across the whole life cycle of biofuels, GHG emission, and primary energy usage can be reduced. Xing et al. [20] calculated and evaluated the land use and water and 
energy consumption of three feedstocks, namely, rape seed oil, Jatropha curcas L. oil, and waste oil, using LCA that considered planting, harvesting, transportation, pretreatment, biodiesel production, distribution, and consumption. Hu et al. established a life cycle energy consumption and emission assessment model for soybean, rape seed, Cornus wilsoniana wanaer (CWW), and Jatropha curcas L. as bases for biodiesel [21]. Wang and Lu analyzed the life cycle energy consumption and pollutant emissions during biodiesel production from Jatropha curcas [22]. The costs, energy consumption, and environmental impact of a bioethanol life cycle that used wheat, corn, and sweet potato as raw materials were analyzed by Zhang [23]. Dai et al. [24] evaluated the energy efficiency of the cassava fuel ethanol life cycle in the Guangxi province, China. Nguyen et al. [25] assessed the energy balance and GHG emissions of the cassava fuel ethanol life cycle in Thailand. Sobrino et al. [1] compared energy consumption of bioliquid fuels with fossil fuels throughout the life cycle and found a lower consumption of primary energy and $\mathrm{CO}_{2}$ emission reduction after bioliquid fuel replaced certain fossil fuels. Razon and Tan [26] analyzed the net energy gain of bioliquid fuel and biogas using algae. Finally, Lu et al. [27] and $\mathrm{Li}$ et al. [28] established the energy and GHG reduction potential of Pistacia chinensis.

Most of the current literature is devoted to experimental or theoretical evaluations in estimating the GHG reduction effects of a certain energy plant for unit volume or mass using LCA. The mean value is used when applied on a district level [29]. The result is that the spatial differences in the GHG reduction potential resulting from the spatial heterogeneity of climate, soil, and terrain features cannot be determined. Hence, the GHG reduction potential is difficult to evaluate on a regional scale.

Addressing this problem, some studies proposed introducing spatial data and spatial analysis methods that couple LCA with GIS to evaluate the GHG reduction potential. A multifactor analysis method based on geographic information system (GIS) techniques was adopted to identify marginal lands for bioenergy development. Marginal lands with potential for planting energy plants were identified for each $1 \mathrm{~km} \times 1 \mathrm{~km}$ grid across China. The net energy and emission reduction efficiency of biological liquid fuel were identified at each grid and the total GHG emission reduction was then obtained by accumulating the grids [30]. GIS techniques and multifactor comprehensive analysis methods are applied to calculate the potential for planting large-scale cassava in Southwest China. Then, the life cycle net energy and GHG emission reduction capacities of cassava on marginal land with different suitability degrees were calculated based on the expanded life cycle model for cassava ethanol fuel. The results indicate that adopting spatial data (such as the climate, soil, and terrain conditions) as well as a spatial analysis model provides a preliminary solution to solve the GHG reduction evaluation problem on a regional scale. The more reasonable results for GHG reduction potential were estimated at relatively fine geographical scale [31]. Dresen and Jandewerth integrated spatial analyses into LCA-calculated GHG emissions with GIS systems. Using the example of the energetic utilization of biomass via conditioned biogas, the authors presented a GIS-based calculation tool that combines geodata on biomass potentials, infrastructure, land use, cost, and technology with analysis tools for the planning of biogas plants to identify the most efficient plant locations and to calculate the emission balances, biomass streams, and costs in the lower Rhine region and the Altmark region in Germany. The results of the GHG balances were presented. The balances of the individual sites, the regional balances, and their temporal development can be calculated in GIS using LCA methods. GIS tools not only allow the assessment of individual plants but also allow the determination of the GHG reduction potential, the biogas potential, and the necessary investment costs for entire regions. Thus, exploiting regional biogas potentials in a way that is sustainable and climate-friendly becomes simple [32]. Environmental integration, such as GIS and LCA, provides a methodology capable of providing enough information and results to determine an energy crop implementation strategy for reducing the energy consumption and $\mathrm{CO}_{2}$ eq. emissions. The methodology was applied and verified in a study area in Catalonia (southern Europe). The results showed that a high impact reduction in GHG could be achieved annually (annual reduction of $1,954,904 \mathrm{Mg}$ of $\mathrm{CO}_{2}$ eq.) [33]. However, some obvious problems remain in the current research. The same parameters were used in the "GHG reduction efficiency" model without considering natural or social conditions. Meanwhile, the total GHG emission reduction potential is not exactly equal to the sum of the grid values, as mutual influences and interactions exist between each grid [29].

\section{Model}

In recent years, many methods, including LCA, have been widely used in bioenergy assessment studies. However, previous studies typically only calculated the unit mass or unit area of a biofuel life cycle based on a laboratory dataset, that is, the "GHG emission reduction efficiency." Regional total GHG emission reduction potentials were simply considered as "efficiency times total yield." The spatiotemporal variation of environmental factors, such as solar radiation, temperature, soil, and water, was not well described in previous studies. To solve this problem, various models have been adopted for estimating the GHG emission of energy plants. IPCC Tier 1 provided a very practical method for calculating GHG emissions. Ecosystem process models and land surface models have also been used. According to the latest progress in this field, the process-based biogeochemical models were introduced into the framework of LCA to quantitatively calculate the $\mathrm{C}, \mathrm{N}$, and GHG emissions during the growth of energy plants and obtain their spatial distribution as well.

3.1. Three-Tier Approaches of IPCC. De Klein et al. (New Zealand) used a three-tier approach to estimate the nitrous oxide $\left(\mathrm{N}_{2} \mathrm{O}\right)$ emissions from managed soils, including indirect $\mathrm{N}_{2} \mathrm{O}$ emissions from the additions of $\mathrm{N}$ to land due to deposition and leaching and emissions of carbon dioxide $\left(\mathrm{CO}_{2}\right)$ following the additions of liming materials and ureacontaining fertilizer. In the most basic form, direct $\mathrm{N}_{2} \mathrm{O}$ 
emissions from managed soils are estimated using Tier 1 methods ((A.1); see the appendix). If more detailed emission factors and corresponding activity data are available to a country than are presented in Tier 1, then Tier 2 can be undertaken. Tier 3 methods are modeling or measurement approaches that can relate the soil and environmental variables responsible for $\mathrm{N}_{2} \mathrm{O}$ emissions to the sizes of those emissions [34]. Tier 1 methods were most widely used because of the data acquisition convenience. Ruesch and Gibbs created a new global map using the IPCC Tier 1 method of biomass carbon stored in above- and below-ground living vegetation. However, the methods they employed are not directly linked to ground-based measures of carbon stocks and have not been validated with field data [35]. At the national level, the intergovernmental panel on climate change (IPCC) has produced a set of guidelines for estimating the GHG inventories at different tiers of quality, ranging from Tier 1 up to Tier 3. The biome averages used in the Tier 1 approach to estimate forest carbon stocks are freely and immediately available and currently provide the only source of globally consistent forest carbon information; however, there are uncertainties caused by natural disturbance, topography, microclimate, and soil type. Additionally, the estimates may be too high or too low for some locations. A study suggested that the default values used in this approach underestimate the carbon stocks for ecosystems, such as temperate moist forests [3639]. In addition to the weaknesses above, the IPCC guidelines provide the default values of regular crops without the default values of most specific energy plants, such as sugarcane, Miscanthus and Cassava.

3.2. Ecosystem Process Model and Land Surface Model. Wu et al. used a modified version of the soil and water assessment tool (SWAT) as a basic tool to simulate a series of biofuel production scenarios involving crop rotation and land cover changes in the James River Basin of the Midwestern United States. The grasslands could be classified based on the simulations in terms of biomass productivity and nitrogen loads. The group further derived the relationship of biomass production targets and the resulting nitrogen loads, and they projected the annual average water yield $\mathrm{NO}_{3}-\mathrm{N}$ load and soil $\mathrm{NO}_{3}-\mathrm{N}$ concentration during the 18 -year simulation period (1991-2008) [40]. PnET (photosynthetic/evapotranspiration model) is a nested series of models of carbon, water, and nitrogen dynamics for forest ecosystems. The models were developed and validated in the Northeastern USA at both the site and the grid level (to $1 \mathrm{~km}$ resolution) by Aber et al. [41]. To contribute toward more reliable estimates of the $\mathrm{N}_{2} \mathrm{O}$ source strength of tropical rainforest ecosystems on a regional scale, Kiese et al. modified a process-oriented biogeochemical model, PnET-N-DNDC, and parameterized it to simulate $\mathrm{C}$ and $\mathrm{N}$ turnover and the production of associated $\mathrm{N}_{2} \mathrm{O}$ emissions in and from tropical rainforest ecosystems. The daily simulated $\mathrm{N}_{2} \mathrm{O}$ emissions based on site data were in good agreement (model efficiencies up to 0.83 ) with field observations in the wet tropics of Australia and Costa Rica [42]. A simulation model, Wetland-DNDC, for $\mathrm{C}$ dynamics and methane $\left(\mathrm{CH}_{4}\right)$ emissions in wetland ecosystems was reported; the model's main structure was adopted from PnET-N-DNDC. The model has been validated against various observations from three wetland sites in Northern America. The validation results agree with the field measurement data [43]. Predictions using PnET-II at the stand or community level indicated that the lumped parameter approach worked well at both large (i.e., multiple community types) and small (within community types) spatial scales $[44,45]$. However, this type of approach will provide inaccurate parameter estimates without the right "mix" of species to offset over- and underestimates because the mixture of species resulted in a compensating error [46].

3.3. Biogeochemical Process Models. DAYCENT is a daily time series biogeochemical model used in agroecosystems to simulate the fluxes of carbon and nitrogen in the atmosphere, vegetation, and soil $[47,48]$. The model is a version of the CENTURY biogeochemical model using a daily scale. The DAYCENT land surface submodel simulated the soil water and soil temperature dynamics well for a variety of sites ranging from dry grassland, wet managed grassland, and wet crop land systems. The simulated results were compared with observed snow cover data, weekly $0-10 \mathrm{~cm}$ soil water data, daily AET data, and soil temperature data. The $r^{2}$ values from the observed versus simulated results were between 0.58 and 0.96 [49]. The ability of DAYCENT to simulate $\mathrm{NPP}$, soil organic carbon, $\mathrm{N}_{2} \mathrm{O}$ emissions, and $\mathrm{NO}_{3}$ leaching has been tested with data from various native and managed systems [50-52]. The DAYCENT biogeochemical model was used to represent GHG emissions more realistically for nonrice major crop types (corn, wheat, and soybean). The results indicate a significant potential to the reduce GHG emissions from cropped soils and to increase yields. Using nitrification inhibitors and split fertilizer applications both led to increased $(\sim 6 \%)$ crop yields, but the inhibitor led to a larger reduction in $\mathrm{N}$ losses $(\sim 10 \%)$. No-till cultivation, which led to $\mathrm{C}$ storage, combined with nitrification inhibitors resulted in reduced GHG emissions of $\sim 50 \%$ and increased crop yields of $\sim 7 \%$ [53]. DAYCENT, used in this study, is likely to be an improvement over the IPCC method that estimates $\mathrm{N}_{2} \mathrm{O}$ emissions based solely on $\mathrm{N}$ inputs and does not account for weather and soil class. However, the dataset used during the simulation was mapped to an extremely coarse resolution at 1.9 olutio, and the nonspatial data (e.g., rates and dates of fertilizer applications) were assumed to be identical within crop types across regions. Lee et al. calibrated and validated DAYCENT and predicted the biomass yield potential of switchgrass across the Central Valley of California. Six common cultivars were calibrated using published data across the USA and validated with data generated from four field trials in California (2007-2009). After calibration and validation, the model explained 66$90 \%$ of observed yield variation in 2007-2009. The model (2.0-9.9 $\mathrm{Mg} \mathrm{ha}^{-1} \mathrm{yr}^{-1}$ ) agreed well with the observed yield variance $\left(1.3-12.2 \mathrm{Mg} \mathrm{ha}^{-1} \mathrm{yr}^{-1}\right.$ ) in the establishment year. The Alamo and Kanlow cultivars were estimated to have biomass production potential within the Central Valley of California under the selected management practices. The 
biomass management options of switchgrass were suggested to differ depending on the temperature and on the yields of the different ecotypes [54].

RothC-26.3 was originally developed and parameterized to model the organic $\mathrm{C}$ turnover in arable topsoils from the Rothamsted long term field experiments, hence the name. The model uses a monthly time step to calculate the total organic carbon $\left(\mathrm{t} \mathrm{ha}^{-1}\right)$, microbial biomass carbon $\left(\mathrm{t} \mathrm{ha}^{-1}\right)$, and D14C (from which the equivalent radiocarbon age of the soil can be calculated) on timescales from years to centuries [55-58]. The model has been evaluated for a range of climates and vegetation types (e.g., cropland, grassland, and forests) and has been previously used for prediction on both regional and global scales [59-64]. Hillier et al. have conducted a study for England and Wales, using the yield maps of four bioenergy crops, Miscanthus (Miscanthus giganteus), short rotation coppice (SRC) poplar (Populus trichocarpa Torr. \& Gray $P$. trichocarpa, var. Trichobel), winter wheat, and oilseed rape, with RothC to simulate the soil $C$ turnover over a 20year period. The GHG emissions from soil are placed in context with the life cycle emissions and then quantify the potential fossil fuel $\mathrm{C}$ that could be displaced. The GHG balance is estimated for each of the 12 land use change transitions associated with replacing arable, grassland, or forest/seminatural land with each of the four bioenergy crops. Miscanthus and SRC are likely to have a mostly beneficial impact in reducing GHG emissions, while oilseed rape and winter wheat have either a net GHG cost or only a marginal benefit [65].

Biome-BGC version 4.1.2 was provided by Peter Thornton at the National Center for Atmospheric Research (NCAR, sponsored by the National Science Foundation) and by the Numerical Terradynamic Simulation group (NTSG) at the University of Montana. The model is a computer model that simulates the storage and fluxes of water, carbon, and nitrogen within the vegetation, litter, and soil components of a terrestrial ecosystem. Biome-BGC is primarily a research tool and many versions have been developed for particular purposes [66]. Biome-BGC was applied to simulate the behavior of three Mediterranean species (Quercus ilex L., Quercus cerris L., and Pinus pinaster Ait.) [67]. The model was also adapted to managed stands with long term observations of biomass production. The exercise includes a model analysis for 33 stands exemplifying typical forest management of beech, oak, pine, and spruce, that is, the four major tree species important to Central-European forestry [68]. In this area, Schmid et al. analyzed the carbon dynamics along an altitudinal gradient across the alpine treeline; the analysis provided insights into the sensitivity of simulated average carbon pools to the changes in environmental factors [69]. The Biome-BGC model was also applied in a forested area of Sweden. The current carbon balance of the forested area and its sensitivity to global change was simulated [70]. Eastaugh et al. applied the species-specific adaptation of the biogeochemical model Biome-BGC to Norway spruce across a range of Austrian climatic change zones using the Austrian National Forest Inventory. The relative influence of current climate change on forest growth was quantified. At the national scale, climate change was found to have negligible effect on Norway spruce productivity, due in part to opposing effects at the regional level [71]. Based on the Biome-BGC model, a modified net primary productivity (NPP) calculation is used to estimate the Jatropha curcas Linnaeus (JCL) yields. A zoning scheme that considers land cover status and potential yield levels was formulated and used to evaluate the potential area and production of future plantations at the global, regional, and national levels. The estimated potential area of JCL plantations is 59-1486 million hectares worldwide and the potential production is 56-3613 million ton dry seed $\mathrm{y}^{-1}$ [72]. The Biome-BGC outputs are useful for the following: (1) establishing the amount and distribution of $\mathrm{C}$ storage by plants; (2) predicting the behavior of different ecosystems in cases of $\mathrm{CO}_{2}$ concentration changes in the air; (3) exploring the controls of water stress and drought on plant carbon balances; (4) exploring the interannual variability of climate on growing season; and (5) furnishing important parameters useful to managing ecosystems, particularly forests [67].

The models most used for energy plant GHG simulations are listed in Table 1. It is worth noting that hundreds of different types of models have been used in the literature. Table 1 presents only select models that are relatively operable and widely applied.

\section{Discussion and Conclusion}

During the last decade, great effort has been directed at establishing an efficient method for comprehensively estimating the GHG emission reduction potential from largescale cultivation of energy plants by combining LCA with ecosystem/biogeochemical process models. LCA presents a general framework for evaluating the energy consumption and GHG emission from energy crop plantation, yield acquisition, production, product use, and postprocessing. Meanwhile, ecosystem/biogeochemical process models are adopted to simulate the fluxes and storage of energy, water, carbon, and nitrogen in the soil-plant (energy crops) soil continuum. Although clear progress has been made in recent years, some problems remain in current studies and should be addressed.

(1) Localization of key parameters: in some of the "GHG reduction efficiency" models, such as [27, 31] the key parameters are derived from the reference values of the American Oregon National Laboratory. The same parameters were used without considering local geographical and social conditions. Good examples of models that incorporate geographical and social conditions were presented by Qin et al. [73] and Gelfand et al. [74]. The terrestrial ecosystem model (TEM), a process-based global-scale ecosystem model, was used to estimate the $\mathrm{C}$ fluxes and pool sizes of switchgrass and Miscanthus in China. For each crop, TEM was calibrated against driving data and the rate limiting parameters for several biogeochemical processes were obtained from the parameterization [73]. Many more details regarding the parameterization of the process model were also presented in 
TABLE 1: Models mostly used for GHG simulation of energy plant.

\begin{tabular}{|c|c|c|c|}
\hline Model & Study object & Study area & Author(s) \\
\hline \multirow{2}{*}{ Tier 1} & Vegetation & Global & Ruesch and Gibbs 2008 [35] \\
\hline & Eucalyptus regnans forests & Australian & Keith et al. 2009 [36] \\
\hline SWAT & Biofuel & $\begin{array}{l}\text { James River Basin of the Midwestern } \\
\text { United States }\end{array}$ & Wu et al. $2012[40]$ \\
\hline \multirow{3}{*}{ PnET } & Forest ecosystems & Northeastern USA & Aber et al. 2005 [41] \\
\hline & Tropical rainforest ecosystems & Wet tropics of Australia and Costa Rica & Kiese et al. 2005 [42] \\
\hline & Wetland & Northern America & Zhang et al. 2002 [43] \\
\hline \multirow{4}{*}{ DAYCENT } & $\begin{array}{l}\text { Dry grassland, wet managed grassland, } \\
\text { and wet crop land systems }\end{array}$ & Minneapolis, Minnesota, USA & Parton et al. 1994 [49] \\
\hline & Crops & USA & del Grosso et al. 2005 [50] \\
\hline & Corn, wheat, and soybean & Worldwide & del Grosso et al. 2009 [53] \\
\hline & Switchgrass & The Central Valley of California & Lee et al. 2012 [54] \\
\hline \multirow{3}{*}{ RothC } & Cropland & European Russia and the Ukraine & Smith et al. 2007 [59] \\
\hline & Nonwaterlogged soils & $\begin{array}{l}\text { Germany, England, the USA, the } \\
\text { Czech Republic, and Australia }\end{array}$ & Coleman et al. 1997 [60] \\
\hline & $\begin{array}{l}\text { Miscanthus, poplar, winter wheat, and } \\
\text { oilseed rape }\end{array}$ & England and Wales & Hillier et al. 2009 [65] \\
\hline \multirow{4}{*}{ Biome-BGC } & $\begin{array}{l}\text { Quercus ilex L., Quercus cerris L., and } \\
\text { Pinus pinaster Ait. }\end{array}$ & The Mediterranean area & Chiesi et al. 2007 [67] \\
\hline & Beech, oak, pine, and spruce & Central-European forestry & Cienciala and Tatarinov 2006 [68] \\
\hline & Forest & Central-European forestry & Schmid et al. 2006 [69] \\
\hline & Forest & Sweden & Lagergren et al. 2006 [70] \\
\hline \multirow{2}{*}{ Biome } & Norway spruce & Austrian & Eastaugh et al. $2011[71]$ \\
\hline & Jatropha curcas Linnaeus & Global & Li et al. 2010 [72] \\
\hline
\end{tabular}

[74]. To achieve qualified and reliable results, the localization of key parameters and sensitivity analysis are very important and worth greater attention in further studies.

(2) Acquisition of spatially explicit estimations: the total GHG emission reduction potential is not simply equal to the sum of the grid values, as in the BiomeBGC model. Mutual influences and interactions exist between each grid [29]. For example, the BiomeBGC team recently presented a new model, the regional hydrological and ecological simulation system (RHESSys), that combines the terrestrial ecosystem process model Biome-BGC with spatially explicit meteorological information and the TOPMODEL hydrologic routing model to make spatial and temporal predictions of carbon, water, and nitrogen dynamics over landscapes [75]. Xu et al. suggested developing a spatially explicit agent-based LCA analysis framework for improving the environmental sustainability of bioenergy systems [76]. Hence, spatially explicit process-based biogeochemical models are much important for deriving both the amount and the spatial distribution of the $\mathrm{C}, \mathrm{N}$, and $\mathrm{GHG}$ emissions during the growth of energy plants. Using these models, the GHG reduction efficiency of scale development of energy plants can be accurately evaluated.
(3) Assessment of the effect of management system. The effect of management system has been neglected in many existing models. However, the environmental policy integrated climate (EPIC), provided by Blackland Research \& Extension Center and USDA Grassland, Soil, and Water Laboratory, could predict the effects of management decisions on soil, water, nutrient, and pesticide movements [77]. Gelfand et al. implemented an EPIC-based spatially explicit integrative modeling framework to simulate the yields of perennial species grown on marginal lands across the ten-state study area in the US north-central region [74]. The international institute for applied systems analysis (IIASA) suggests that EPIC has accurately simulated the agricultural conditions and practices for hundreds of years into the past, providing an excellent basis for projecting future trends in global change [78]. Therefore, more attention should be paid to the management system or the practice of energy crop plantation in future studies.

\section{Appendix}

Consider

$$
\begin{aligned}
\mathrm{N}_{2} \mathrm{O}_{\text {Direct }}-\mathrm{N}= & \mathrm{N}_{2} \mathrm{O}-\mathrm{N}_{\mathrm{N} \text { inputs }}+\mathrm{N}_{2} \mathrm{O}-\mathrm{N}_{\mathrm{OS}} \\
& +\mathrm{N}_{2} \mathrm{O}-\mathrm{N}_{\text {PRP }}
\end{aligned}
$$




$$
\begin{aligned}
\mathrm{N}_{2} \mathrm{O}-\mathrm{N}_{\mathrm{N} \text { inputs }}=[ & {\left[\left(F_{\mathrm{SN}}+F_{\mathrm{ON}}+F_{\mathrm{CR}}+F_{\mathrm{SOM}}\right) \cdot \mathrm{EF}_{1}\right] } \\
& \left.+\left[\left(F_{\mathrm{SN}}+F_{\mathrm{ON}}+F_{\mathrm{CR}}+F_{\mathrm{SOM}}\right)_{\mathrm{FR}}+\mathrm{EF}_{1 \mathrm{FR}}\right]\right] \\
\mathrm{N}_{2} \mathrm{O}-\mathrm{N}_{\mathrm{OS}}=[ & \left(F_{\mathrm{OS}, \mathrm{CG}, \mathrm{Temp}} \cdot \mathrm{EF}_{2 \mathrm{CG}, \mathrm{Temp}}\right) \\
+ & +\left(F_{\mathrm{OS}, \mathrm{CG}, \mathrm{Trop}} \cdot \mathrm{EF}_{2 \mathrm{~F}, \mathrm{Temp}, \mathrm{NP}}\right) \\
& +\left(F_{\mathrm{OS} . \mathrm{F} . \mathrm{Temp}, \mathrm{NR}} \bullet \mathrm{EF}_{2 \mathrm{~F}, \mathrm{Temp}, \mathrm{NR}}\right) \\
& +\left(F_{\mathrm{OS}, \mathrm{F}, \mathrm{Temp}, \mathrm{NP}} \bullet \mathrm{EF}_{2 \mathrm{~F}, \mathrm{Temp}, \mathrm{nP}}\right) \\
& \left.+\left(F_{\mathrm{OS}, \mathrm{F}, \mathrm{Trop}} \bullet \mathrm{EF}_{2 \mathrm{~F}, \mathrm{Trop}}\right)\right] \\
\mathrm{N}_{2} \mathrm{O}-\mathrm{N}_{\mathrm{PRP}}= & {\left[\left(F_{\mathrm{PRP}, \mathrm{CPP}} \cdot \mathrm{EF}_{3 \mathrm{PRP}, \mathrm{CPP}}\right)\right.} \\
& \left.+\left(F_{\mathrm{PRP}, \mathrm{SO}} \bullet \mathrm{EF}_{3 \mathrm{PRP}, \mathrm{SO}}\right)\right]
\end{aligned}
$$

where

$\mathrm{N}_{2} \mathrm{O}_{\text {Direct }}-\mathrm{N}=$ annual direct $\mathrm{N}_{2} \mathrm{O}-\mathrm{N}$ emissions produced from managed soils, $\mathrm{kg} \mathrm{N}_{2} \mathrm{O}-\mathrm{N} \mathrm{yr}^{-1}$,

$\mathrm{N}_{2} \mathrm{O}-\mathrm{N}_{\text {Ninputs }}=$ annual direct $\mathrm{N}_{2} \mathrm{O}-\mathrm{N}$ emissions from $\mathrm{N}$ inputs to managed soils, $\mathrm{kg} \mathrm{N}_{2} \mathrm{O}-\mathrm{N} \mathrm{yr}^{-1}$,

$\mathrm{N}_{2} \mathrm{O}-\mathrm{N}_{\mathrm{OS}}=$ annual direct $\mathrm{N}_{2} \mathrm{O}-\mathrm{N}$ emissions from managed organic soils, $\mathrm{kg} \mathrm{N}_{2} \mathrm{O}-\mathrm{N} \mathrm{yr}^{-1}$,

$\mathrm{N}_{2} \mathrm{O}-\mathrm{N}_{\text {PRP }}=$ annual direct $\mathrm{N}_{2} \mathrm{O}-\mathrm{N}$ emissions from urine and dung inputs to grazed soils, $\mathrm{kg} \mathrm{N}_{2} \mathrm{O}-\mathrm{N} \mathrm{yr}^{-1}$,

$F_{\mathrm{SN}}=$ annual amount of synthetic fertilizer $\mathrm{N}$ applied to soils, $\mathrm{kg} \mathrm{N} \mathrm{yr}^{-1}$,

$F_{\mathrm{ON}}=$ annual amount of animal manure, compost, sewage sludge, and other organic $\mathrm{N}$ additions applied to soils (note: if including sewage sludge, cross-check with waste sector to ensure that the $\mathrm{N}_{2} \mathrm{O}$ emissions are not double-counted from the $\mathrm{N}$ in sewage sludge), $\mathrm{kg} \mathrm{N} \mathrm{yr}^{-1}$,

$F_{\mathrm{CR}}=$ annual amount of $\mathrm{N}$ in crop residues (aboveground and below-ground), including $\mathrm{N}$-fixing crops, and from forage/pasture renewal, returned to soils, $\mathrm{kg} \mathrm{N} \mathrm{yr}^{-1}$,

$F_{\text {SOM }}=$ annual amount of $\mathrm{N}$ in mineral soils that is mineralized, in association with loss of soil $\mathrm{C}$ from soil organic matter as a result of changes to land use or management, $\mathrm{kg} \mathrm{N} \mathrm{yr}^{-1}$,

$F_{\mathrm{OS}}=$ annual area of managed/drained organic soils, ha (note: the subscripts CG, F, Temp, Trop, NR, and NP refer to cropland and grassland, forest land, temperate, tropical, nutrient rich, and nutrient poor, resp.),

$F_{\mathrm{PRP}}=$ annual amount of urine and dung $\mathrm{N}$ deposited by grazing animals on pasture, range, and paddock, $\mathrm{kg} \mathrm{Nyr}^{-1}$ (note: the subscripts CPP and SO refer to cattle, poultry, and pigs and sheep and other animals, resp.),
$\mathrm{EF}_{1}=$ emission factor for $\mathrm{N}_{2} \mathrm{O}$ emissions from $\mathrm{N}$

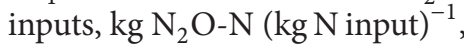

$\mathrm{EF}_{1 \mathrm{FR}}$ is the emission factor for $\mathrm{N}_{2} \mathrm{O}$ emissions from $\mathrm{N}$ inputs to flooded rice, $\mathrm{kg} \mathrm{N}_{2} \mathrm{O}-\mathrm{N}$ (kg Ninput) ${ }^{-1}$,

$\mathrm{EF}_{2}=$ emission factor for $\mathrm{N}_{2} \mathrm{O}$ emissions from drained/managed organic soils, $\mathrm{kg} \mathrm{N}_{2} \mathrm{O}-\mathrm{N} \mathrm{ha}^{-1} \mathrm{yr}^{-1}$; (note: the subscripts CG, F, Temp, Trop, NR, and NP refer to cropland and grassland, forest land, temperate, tropical, nutrient fich, and nutrient poor, resp.),

$\mathrm{EF}_{3 \mathrm{PRP}}=$ emission factor for $\mathrm{N}_{2} \mathrm{O}$ emissions from urine and dung $\mathrm{N}$ deposited on pasture, range, and paddock by grazing animals, $\mathrm{kg} \mathrm{N}_{2} \mathrm{O}-\mathrm{N}$ $(\mathrm{kg} \mathrm{N} \text { input })^{-1}$ (note: the subscripts $\mathrm{CPP}$ and SO refer to cattle, poultry, and pigs, and sheep and other animals, resp.).

\section{Conflict of Interests}

The authors declare that there is no conflict of interest regarding the publication of this paper.

\section{Acknowledgments}

The work presented here was supported by the Chinese Academy of Sciences (Grant no. KZZD-EW-08) and the Chinese Earthquake Administration (Grant no. 201208018$3)$.

\section{References}

[1] F. Hernandez Sobrino, C. Rodriguez Monroy, and J. Luis Hernandez Perez, "Biofuels and fossil fuels: Life Cycle Analysis (LCA) optimisation through productive resources maximisation," Renewable \& Sustainable Energy Reviews, vol. 15, no. 6, pp. 2621-2628, 2011.

[2] I. Gelfand, R. Sahajpal, X. Zhang, R. C. Izaurralde, K. L. Gross, and G. P. Robertson, "Sustainable bioenergy production from marginal lands in the US Midwest," Nature, vol. 493, no. 7433, pp. 514-517, 2013.

[3] B. Dudley, BP Statistical Review of World Energy, 2012.

[4] E. Martinot, "Renewables 2005," Global Status Report, Worldwatch Institute, Washington, DC, USA, 2005.

[5] J. Hill, E. Nelson, D. Tilman, S. Polasky, and D. Tiffany, "Environmental, economic, and energetic costs and benefits of biodiesel and ethanol biofuels," Proceedings of the National Academy of Sciences of the United States of America, vol. 103, no. 30, pp. 11206-11210, 2006.

[6] P. R. Adler, S. J. D. Grosso, and W. J. Parton, "Life-cycle assessment of net greenhouse-gas flux for bioenergy cropping systems," Ecological Applications, vol. 17, no. 3, pp. 675-691, 2007.

[7] W. Thompson, S. Meyer, and T. Green, "The U.S. biodiesel use mandate and biodiesel feedstock markets," Biomass \& Bioenergy, vol. 34, no. 6, pp. 883-889, 2010.

[8] A. L. Stephenson, J. S. Dennis, and S. A. Scott, "Improving the sustainability of the production of biodiesel from oilseed rape in the UK," Process Safety and Environmental Protection, vol. 86, no. 6, pp. 427-440, 2008. 
[9] S. Gmünder, R. Singh, S. Pfister, A. Adheloya, and R. Zah, "Environmental impacts of Jatropha curcas biodiesel in India," Journal of Biomedicine \& Biotechnology, vol. 2012, Article ID 623070, 10 pages, 2012.

[10] J. Fargione, J. Hill, D. Tilman, S. Polasky, and P. Hawthorne, "Land clearing and the biofuel carbon debt," Science, vol. 319, no. 5867, pp. 1235-1238, 2008.

[11] T. Searchinger, R. Heimlich, R. A. Houghton et al., "Use of U.S. croplands for biofuels increases greenhouse gases through emissions from land-use change," Science, vol. 319, no. 5867, pp. 1238-1240, 2008.

[12] U. Congress, "Energy independence and security act of 2007," Public Law, no. 110-140: p. 2, 2007.

[13] Energy, U.S.D.o. DOE Actively Engaged in Investigating the Role of Biofuels in Greenhouse Gas Emissions from Indirect Land Use Change, 2008.

[14] A. E. Farrell, R. J. Plevin, B. T. Turner, A. D. Jones, M. O'Hare, and D. M. Kammen, "Ethanol can contribute to energy and environmental goals," Science, vol. 311, no. 5760, pp. 506-508, 2006.

[15] M. R. Schmer, K. P. Vogel, R. B. Mitchell, and R. K. Perrin, "Net energy of cellulosic ethanol from switchgrass," Proceedings of the National Academy of Sciences of the United States of America, vol. 105, no. 2, pp. 464-469, 2008.

[16] N. Sasaki, W. Knorr, D. R. Foster et al., "Woody Biomass \& Bioenergy potentials in Southeast Asia between 1990 and 2020," Applied Energy, vol. 86, no. 1, pp. S140-S150, 2009.

[17] F. Richter, "Financial and economic assessment of timber harvesting operations in Sarawak, Malaysia," Forest Harvesting Case-Study, 2001.

[18] E. I. Administration, International Energy Outlook 2006, EIA, Office of Integrated Analysis and Forecasting, US Department of Energy, Washington, DC, USA, 2006.

[19] W. Wu and H. Jikun, Potential Land for Plantation of Jatropha Curcas as Feedstocks for Biodiesel in Southwest China, China Agriculture Press, Beijing, China, 2010.

[20] A.-H. Xing, J. Ma, Y.-H. Zhang, Y. Wang, and Y. Jin, "Life cycle assessment of resource and energy consumption for production of biodiesel," The Chinese Journal of Process Engineering, vol. 10, no. 2, pp. 314-320, 2010.

[21] Z. Hu, P. Tan, D. Lou, and Y. Dong, "Assessment of life cycle energy consumption and emissions for several kinds of feedstock based biodiesel," Transactions of the Chinese Society of Agricultural Engineering, vol. 22, no. 11, pp. 141-146, 2006.

[22] Z. X. Wang and Y. Lu, "Jatropha curcas seed oil life cycle of the economy, environment and energy efficiency," Resources and Environment in the Yangtze Basin, vol. 20, no. 001, pp. 61-67, 2011.

[23] C. X. Zhang, Potential and Impact Assessment of Bio-Ethanol in China, Graduate University of Chinese Academy of Sciences, Beijing, China, 2010.

[24] D. Dai, Z. Hu, G. Pu, H. Li, and C. Wang, "Energy efficiency and potentials of cassava fuel ethanol in Guangxi region of China," Energy Conversion and Management, vol. 47, no. 13-14, pp. 1686$1699,2006$.

[25] T. L. T. Nguyen, S. H. Gheewala, and S. Garivait, "Energy balance and GHG-abatement cost of cassava utilization for fuel ethanol in Thailand," Energy Policy, vol. 35, no. 9, pp. 4585-4596, 2007.

[26] L. F. Razon and R. R. Tan, "Net energy analysis of the production of biodiesel and biogas from the microalgae: haematococcus pluvialis and Nannochloropsis," Applied Energy, vol. 88, no. 10, pp. 3507-3514, 2011.

[27] L. Lu, D. Jiang, D. Zhuang, and Y. Huang, "Evaluating the marginal land resources suitable for developing Pistacia chinensis-based biodiesel in China," Energies, vol. 5, no. 7, pp. 2165-2177, 2012.

[28] Y. Li, X. Xie, X. Bin et al., "Study on pilot scale biodiesel production from Pistacia chinensis oil," Renewable Energy Resources, vol. 28, no. 4, pp. 54-57, 2010.

[29] G. Fiorese and G. Guariso, "A GIS-based approach to evaluate biomass potential from energy crops at regional scale," Environmental Modelling \& Software, vol. 25, no. 6, pp. 702-711, 2010.

[30] D. Zhuang, D. Jiang, L. Liu, and Y. Huang, "Assessment of bioenergy potential on marginal land in China," Renewable \& Sustainable Energy Reviews, vol. 15, no. 2, pp. 1050-1056, 2011.

[31] L. Lei, D. Zhuang, D. Jiang et al., "Assessing the potential of the cultivation area and greenhouse gas (GHG) emission reduction of cassava-based fuel ethanol on marginal land in Southwest China," African Journal of Agricultural Research, vol. 7, no. 41, pp. 5594-5603, 2012.

[32] B. Dresen and M. Jandewerth, "Integration of spatial analyses into LCA-calculating GHG emissions with geoinformation systems," International Journal of Life Cycle Assessment, vol. 17, no. 9, pp. 1094-1103, 2012.

[33] C. M. Gasol, X. Gabarrell, M. Rigola, S. González-García, and J. Rieradevall, "Environmental assessment: (LCA) and spatial modelling (GIS) of energy crop implementation on local scale," Biomass \& Bioenergy, vol. 35, no. 7, pp. 2975-2985, 2011.

[34] C. De Klein, R. S. A. Novoa, S. Ogle et al., " $\mathrm{N}_{2} \mathrm{O}$ emissions from managed soils, and $\mathrm{CO}_{2}$ emissions from lime and urea application," in IPCC Guidelines for National Greenhouse Gas Inventories, vol. 4, National Greenhouse Gas Inventories Programme, 2006.

[35] A. Ruesch and H. K. Gibbs, New IPCC Tier-1 Global Biomass Carbon Map for the Year 2000, 2008.

[36] H. Keith, B. G. Mackey, and D. B. Lindenmayer, "Reevaluation of forest biomass carbon stocks and lessons from the world's most carbon-dense forests," Proceedings of the National Academy of Sciences of the United States of America, vol. 106, no. 28, pp. 11635-11640, 2009.

[37] H. K. Gibbs, S. Brown, J. O. Niles, and J. A. Foley, "Monitoring and estimating tropical forest carbon stocks: making REDD a reality," Environmental Research Letters, vol. 2, no. 4, Article ID 045023, 2007.

[38] P. C. West, H. K. Gibbs, C. Monfreda et al., "Trading carbon for food: global comparison of carbon stocks vs. crop yields on agricultural land," Proceedings of the National Academy of Sciences of the United States of America, vol. 107, no. 46, pp. 19645-19648, 2010.

[39] S. N. Djomo and R. Ceulemans, "A comparative analysis of the carbon intensity of biofuels caused by land use changes," $G C B$ Bioenergy, vol. 4, no. 4, pp. 392-407, 2012.

[40] Y. Wu, S. Liu, and Z. Li, "Identifying potential areas for biofuel production and evaluating the environmental effects: a case study of the James River Basin in the Midwestern United States," GCB Bioenergy, vol. 4, no. 6, pp. 875-888, 2012.

[41] J. D. Aber, C. T. Federer, C. A. Ollinger et al., PnET Models: Carbon, Nitrogen, Water Dynamics in Forest Ecosystems (Vers. 4 and 5), vol. 10, Oak Ridge National Laboratory Distributed Active Archive Center, Oak Ridge, Tenn, USA, 2005, http://daac.ornl.gov/. 
[42] R. Kiese, C. Li, D. W. Hilbert, H. Papen, and K. ButterbachBahl, "Regional application of PnET-N-DNDC for estimating the $\mathrm{N} 2 \mathrm{O}$ source strength of tropical rainforests in the wet tropics of Australia," Global Change Biology, vol. 11, no. 1, pp. 128-144, 2005.

[43] Y. Zhang, C. Li, C. C. Trettin, H. Li, and G. Sun, "An integrated model of soil, hydrology, and vegetation for carbon dynamics in wetland ecosystems," Global Biogeochemical Cycles, vol. 16, no. 4, pp. 1-9, 2002.

[44] J. D. Aber and C. A. Federer, "A generalized, lumped-parameter model of photosynthesis, evapotranspiration and net primary production in temperate and boreal forest ecosystems," Oecologia, vol. 92, no. 4, pp. 463-474, 1992.

[45] J. D. Aber, P. B. Reich, and M. L. Goulden, "Extrapolating leaf $\mathrm{CO}_{2}$ exchange to the canopy: a generalized model of forest photosynthesis compared with measurements by eddy correlation," Oecologia, vol. 106, no. 2, pp. 257-265, 1996.

[46] J. M. Vose and P. V. Bolstad, "Challenges to modelling NPP in diverse eastern deciduous forests: Species-level comparisons of foliar respiration responses to temperature and nitrogen," Ecological Modelling, vol. 122, no. 3, pp. 165-174, 1999.

[47] W. J. Parton, M. Hartman, D. Ojima, and D. Schimel, "DAYCENT and its land surface submodel: Description and testing," Global and Planetary Change, vol. 19, no. 1, pp. 35-48, 1998.

[48] S. J. del Grosso, W. J. Parton, P. R. Adler, S. C. Davis, C. Keough, and E. Marx, "Simulated interaction of carbon dynamics and nitrogen trace gas fluxes using the DAYCENT model," Modeling Carbon and Nitrogen Dynamics for Soil Management, pp. 303332, 2012.

[49] W. J. Parton, D. S. Ojima, and C. V. Cole, "A general model for soil organic matter dynamics: sensitivity to litter chemistry, texture and management," in Quantitative Modeling of Soil Forming Processes: Proceedings of a Symposium Sponsored by Divisions S-5 and S-9 of the Soil Science Society of America in Minneapolis, MinnesotA, USA, 2 November 1992, R. B. Bryant and R. W. Arnold, Eds., Soil Science Society of America, 1994.

[50] S. J. del Grosso, A. R. Mosier, W. J. Parton, and D. S. Ojima, "DAYCENT model analysis of past and contemporary soil $\mathrm{N}_{2} \mathrm{O}$ and net greenhouse gas flux for major crops in the USA," Soil and Tillage Research, vol. 83, no. 1, pp. 9-24, 2005.

[51] S. J. Del Grosso, W. J. Parton, A. R. Mosier et al., "Simulated effects of land use, soil texture, and precipitation on $\mathrm{N}$ gas emissions using DAYCENT.," Nitrogen in the Environment: Sources, Problems and Management, pp. 413-431, 2001.

[52] S. del Grosso, D. Ojima, W. Parton, A. Mosier, G. Peterson, and D. Schimel, "Simulated effects of dryland cropping intensification on soil organic matter and greenhouse gas exchanges using the DAYCENT ecosystem model," Environmental Pollution, vol. 116, no. 1, pp. S75-S83, 2002.

[53] S. J. del Grosso, D. S. Ojima, W. J. Parton et al., "Global scale DAYCENT model analysis of greenhouse gas emissions and mitigation strategies for cropped soils," Global and Planetary Change, vol. 67, no. 1-2, pp. 44-50, 2009.

[54] J. Lee, G. Pedroso, B. A. Linquist, D. Putnam, C. van Kessel, and J. Six, "Simulating switchgrass biomass production across ecoregions using the DAYCENT model," GCB Bioenergy, vol. 4, no. 5, pp. 521-533, 2012.

[55] D. Jenkinson, P. Hart, J. Rayner, and L. Parry, "Modelling the turnover of organic matter in long-term experiments at Rothamsted," 1987.

[56] D. S. Jenkinson and K. Coleman, "Calculating the annual input of organic matter to soil from measurements of total organic carbon and radiocarbon," European Journal of Soil Science, vol. 45, no. 2, pp. 167-174, 1994.

[57] D. S. Jenkinson, D. E. Adams, and A. Wild, "Model estimates of $\mathrm{CO}_{2}$ emissions from soil in response to global warming," Nature, vol. 351, no. 6324, pp. 304-306, 1991.

[58] D. S. Jenkinson, S. P. S. Andrew, J. M. Lynch, M. J. Goss, and P. B. Tinker, "The turnover of organic carbon and nitrogen in soil," Philosophical Transactions of the Royal Society of London B, vol. 329, no. 1255, pp. 361-368, 1990.

[59] J. Smith, P. Smith, M. Wattenbach et al., "Projected changes in the organic carbon stocks of cropland mineral soils of European Russia and the Ukraine, 1990-2070," Global Change Biology, vol. 13, no. 2, pp. 342-356, 2007.

[60] K. Coleman, D. S. Jenkinson, G. J. Crocker et al., "Simulating trends in soil organic carbon in long-term experiments using RothC-26.3," Geoderma, vol. 81, no. 1-2, pp. 29-44, 1997.

[61] P. Falloon, P. Smith, R. I. Bradley et al., "RothCUK-a dynamic modelling system for estimating changes in soil C from mineral soils at 1-km resolution in the UK," Soil Use and Management, vol. 22, no. 3, pp. 274-288, 2006.

[62] Y. P. Wang and P. J. Polglase, "Carbon balance in the tundra, boreal forest and humid tropical forest during climate change: scaling up from leaf physiology and soil carbon dynamics," Plant, Cell \& Environment, vol. 18, no. 10, pp. 1226-1244, 1995.

[63] J. O. Skjemstad, L. R. Spouncer, B. Cowie, and R. S. Swift, "Calibration of the Rothamsted organic carbon turnover model (RothC ver. 26.3), using measurable soil organic carbon pools," Australian Journal of Soil Research, vol. 42, no. 1, pp. 79-88, 2004.

[64] P. Smith, J. U. Smith, D. S. Powlson et al., "A comparison of the performance of nine soil organic matter models using datasets from seven long-term experiments," Geoderma, vol. 81, no. 1-2, pp. 153-225, 1997.

[65] J. Hillier, W. Carly, G. Dailey et al., "Greenhouse gas emissions from four bioenergy crops in England and Wales: integrating spatial estimates of yield and soil carbon balance in life cycle analyses," GCB Bioenergy, vol. 1, no. 4, pp. 267-281, 2009.

[66] P. E. Thornton, B. E. Law, H. L. Gholz et al., "Modeling and measuring the effects of disturbance history and climate on carbon and water budgets in evergreen needleleaf forests," Agricultural and Forest Meteorology, vol. 113, no. 1, pp. 185-222, 2002.

[67] M. Chiesi, F. Maselli, M. Moriondo, L. Fibbi, M. Bindi, and S. W. Running, "Application of BIOME-BGC to simulate Mediterranean forest processes," Ecological Modelling, vol. 206, no. 1-2, pp. 179-190, 2007.

[68] E. Cienciala and F. A. Tatarinov, "Application of BIOME-BGC model to managed forests. 2. Comparison with long-term observations of stand production for major tree species," Forest Ecology and Management, vol. 237, no. 1-3, pp. 252-266, 2006.

[69] S. Schmid, B. Zierl, and H. Bugmann, "Analyzing the carbon dynamics of central European forests: comparison of BiomeBGC simulations with measurements," Regional Environmental Change, vol. 6, no. 4, pp. 167-180, 2006.

[70] F. Lagergren, A. Grelle, H. Lankreijer, M. Mölder, and A. Lindroth, "Current carbon balance of the forested area in Sweden and its sensitivity to global change as simulated by Biome-BGC," Ecosystems, vol. 9, no. 6, pp. 894-908, 2006.

[71] C. S. Eastaugh, E. Pötzelsberger, and H. Hasenauer, "Assessing the impacts of climate change and nitrogen deposition on Norway spruce (Picea abies L. Karst) growth in Austria with BIOME-BGC," Tree Physiology, vol. 31, no. 3, pp. 262-274, 2011. 
[72] Z. Li, B.-L. Lin, X. F. Zhao, M. Sagisaka, and R. Shibazaki, "System approach for evaluating the potential yield and plantation of jatropha curcas 1 on a global scale," Environmental Science \& Technology, vol. 44, no. 6, pp. 2204-2209, 2010.

[73] Z. Qin, Q. Zhuang, X. Zhu, X. Cai, and X. Zhang, "Carbon consequences and agricultural implications of growing biofuel crops on marginal agricultural lands in China," Environmental Science \& Technology, vol. 45, no. 24, pp. 10765-10772, 2011.

[74] I. Gelfand, R. Sahajpal, X. Zhang, R. C. Izaurralde, K. L. Gross, and G. P. Robertson, "Sustainable bioenergy production from marginal lands in the US Midwest," Nature, vol. 493, no. 7433, pp. 514-517, 2013.

[75] S. Running, J. Golinkoff, and R. Anderson, "Ecosystem modeling," 2013, http://www.ntsg.umt.edu/taxonomy/term/59.

[76] M. Xu, S. A. Miller, S. Choudhary, and A. Heairet, "Developing a spatially-explicit agentbased life cycle analysis framework for improving the environmental sustainability of bioenergy systems," 2011, http://css.snre.umich.edu/project/developingspatially-explicit-agent-based-life-cycle-analysis-frameworkimproving.

[77] Research, T.A.M.A. EPIC \& APEX Models, http://epicapex.tamu.edu/epic/.

[78] (IIASA), I.I.f.A.S.A. The Environmental Policy Integrated Model (EPIC) - a model assessing how land management affects the environment, 2012, http://www.iiasa.ac.at/web/ho$\mathrm{me} / \mathrm{research} /$ modelsData/EPIC.en.html. 


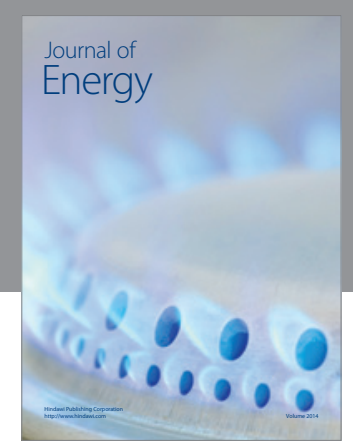

Journal of

Industrial Engineering
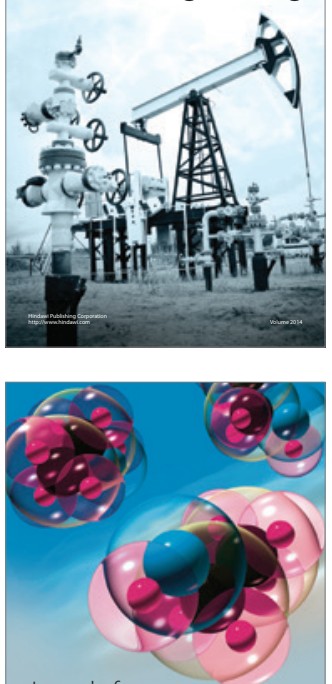

Fuels
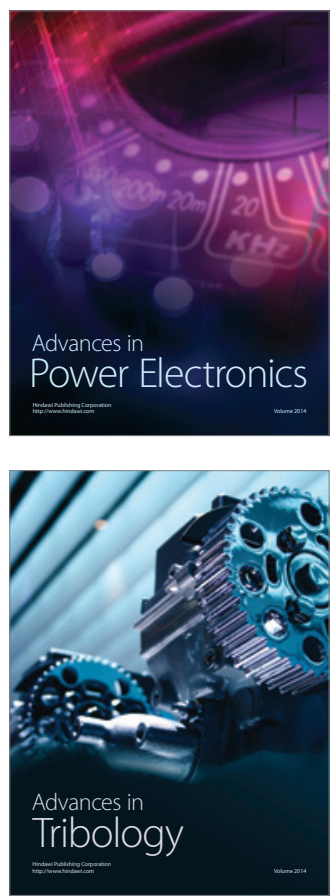

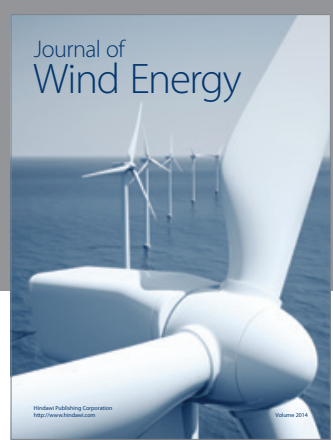

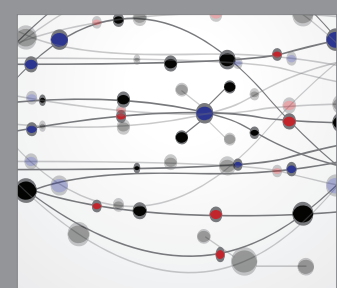

The Scientific World Journal

Submit your manuscripts at http://www.hindawi.com

Journal of

Structures
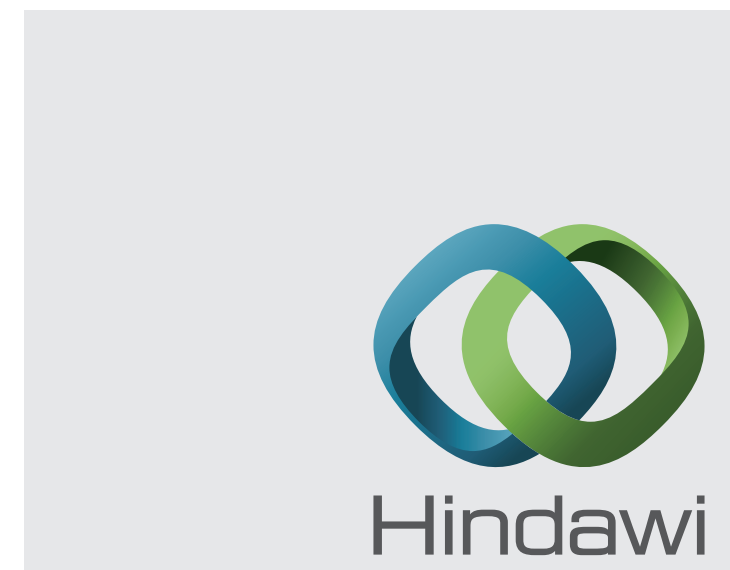

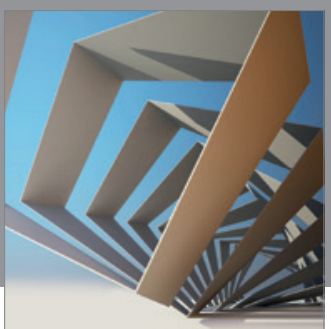

Rotating

Machinery
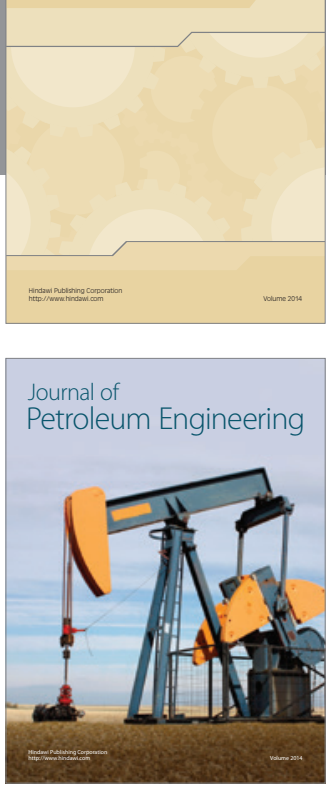

Journal of

Solar Energy
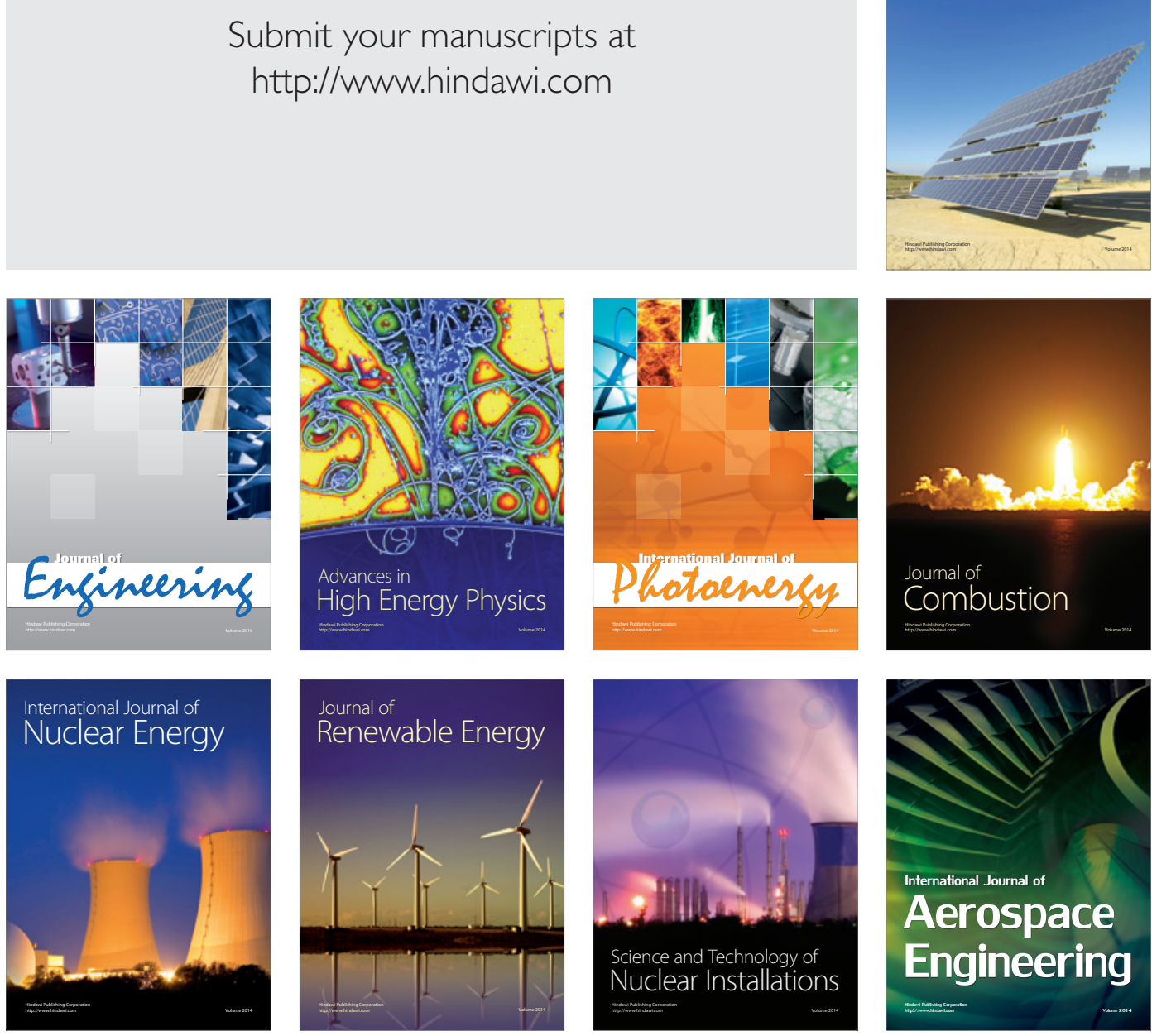